\title{
PENGARUH SENAM KAKI TERHADAP KADAR GULA DARAH PASIEN DIABETES MELITUS DI RSU SERANG PROVINSI BANTEN TAHUN 2014
}

\author{
Elang Wibisana ${ }^{1}$, Yani Sofiani ${ }^{2}$ \\ ${ }^{1}$ Universitas Muhammadiyah Tangerang \\ Jl. Taman Makam Pahlawan (TMP) Taruna No.2, Sukasari, Kota Tangerang \\ ${ }^{2}$ Universitas Muhammadiyah Jakarta \\ Jl. Cempaka Putih Tengah I/1,Jakarta Pusat \\ Email: kmb_elang@yahoo.co.id
}

\begin{abstract}
ABSTRAK
Diabetes Mellitus merupakan gangguan metabolik yang dikarakteristikkan dengan hiperglikemi bersama dengan gangguan metabolisme karbohidrat, lemak, dan protein yang disebabkan oleh defek sekresi insulin dan aksi insulin. Tujuan penelitian ini adalah untuk mengetahui pengaruh senam kaki terhadap kadar gula darah pada pasien diabetes mellitus di RSU Serang. Penelitian ini menggunakan desain quasi eksperimental one group pretest-posttest dengan melibatkan 22 responden. Penelitian ini menggunakan t test, diperoleh hasil adanya perbedaan rata-rata kadar gula darah sebelum dan setelah dilakukan senam kaki ( $p=0.001$; $\alpha=0.05)$. Tidak hanya itu, faktor usia $(p=0.001 ; \alpha=0.05)$, intensitas melakukan senam ( $p=0.002 ; \alpha=0.05)$, konsumsi obat $(p=0.000 ; \alpha=0.05)$ sebagai confounding variabel dilihat pengaruhnya terhadap perubahan kadar gula darah setelah dilakukan senam kaki. Saran untuk penelitian ini bahwa senam kaki diabetes dapat dijadikan salah satu standar asuhan keperawatan yang dapat diaplikasikan dalam pelayanan keperawatan, baik di rumah sakit dan komunitas. Dan untuk penelitian selanjutnya, sebaiknya variable lamanya terkena diabetes harus disertakan dan waktu penelitian harus lebih diperhatikan untuk mengetahui secara pasti efek dari senam kaki diabetes. Hasil dari penelitian ini diharapkan bisa menjadi salah satu bahan kajian, dan rujukan dalam penelitian sejenis.
\end{abstract}

Kata Kunci: senam kaki; kadar gula darah

\author{
EFFECT OF LEG EXERCISE TO BLOOD SUGAR LEVELS IN \\ DIABETES MELLITUS PATIENTS AT SERANG HOSPITALS 2014
}

\begin{abstract}
Diabetes Mellitus is a metabolic disorder characterized by hyperglycemia along with impaired metabolism of carbohydrates, fats, and proteins caused by defects in insulin secretion and insulin action. The purpose of this study was to determine the effect of exercise on leg blood sugar levels in patients with diabetes mellitus in Serang Hospital. This study used a quasi-experimental design one group pretestposttest involving 22 respondents. This study using the $t$ test, the obtained results a significant difference on average in blood sugar levels before and after exercise leg $(p=0001 ; \alpha=0.05$ level $)$. Not only that, the factor of age $(p=0.001 ; \alpha=0.05$ level $)$, intensity of exercise ( $p=0.002 ; \alpha=0.05$ level), drug consumption $(p=0.000 ; \alpha=0.05$
\end{abstract}


level) as confounding variables seen its influence on changes in blood sugar levels after leg exercises. Suggestions for this study that variable duration of diabetes should be included. And for further research, preferably confounding variables and study time should be considered to determine the exact effect of diabetic foot gymnastics. Results from this study is expected to be one of the study materials, and reference in similar research.

Key words : Leg exercise; blood sugar level.

\section{PENDAHULUAN}

Diantara penyakit degeneratif atau penyakit tidak menular yang akan meningkat jumlahnya di masa mendatang adalah Diabetes Mellitus. DM merupakan merupakan gangguan metabolik yang dikarakteristikkan dengan hiperglikemi bersama dengan gangguan metabolisme karbohidrat, lemak, dan protein yang disebabkan oleh defek sekresi insulin dan aksi insulin (Alberti, 2010).

Global Status Report on Non Communicable Diseases (NCDs) World Health Organization (WHO) tahun 2010 melaporkan bahwa $60 \%$ penyebab kematian semua umur di dunia adalah karena penyakit tidak menular, diantara penyakit tersebut DM menduduki peringkat ke-6 di dunia sebagai penyebab kematian, sekitar 1,3 juta orang meninggal akibat diabetes dan $4 \%$ meninggal sebelum usia 70 tahun. Pada Tahun 2030 diperkirakan DM menempati urutan ke-7 penyebab kematian dunia (WHO, 2013). Berdasarkan IDF Diabetes Atlas edisi ke-6 tahun 2013, prevalensi DM di asia pasifik dari populasi 138.200.000 orang dewasa, 8,6\% memiliki diabetes. Selama 20 tahun berikutnya jumlah ini diperkirakan akan meningkat menjadi 201.800.000 (11,1\%) (IDF, 2013).

Berdasarkan data dari RISKESDA 2013, prevalensi DM pada daerah urban sebesar $6,8 \%$ dan rural $7 \%$, dimana penyandang DM laki - laki sebesar 5,6\% dan perempuan $7,7 \%$. Prevalensi DM berdasarkan gejala dan diagnosis sebesar $2,1 \%$. Prevalensi DM yang terdiagnosis dokter tertinggi terdapat di DI Yogyakarta 2,6\%, DKI Jakarta 2,5\%, Sulawesi Utara 2,4\% dan Kalimantan Timur 2,3\%.
Sedangkan Prevalensi di Provinsi Banten sebesar 1,3\% (RISKESDA, 2013).

Pengelolaan DM dapat dilakukan dengan terapi farmakologis dan terapi non farmakologis. Pengelolaan terapi farmakologis yaitu pemberian insulin dan obat hipoglikemik oral. Sedangkan non farmakologis meliputi pengendalian berat badan, latihan olahraga, dan diet. Latihan jasmani merupakan salah satu dari empat pilar utama penatalaksanaan diabetes mellitus (Perkeni, 2006). Latihan jasmani dapat menurunkan kadar glukosa darah karena latihan jasmani akan meningkatkan pemakaian glukosa oleh otot yang aktif (Yunir \& Soebardi, 2009).

Sejalan dengan hal tersebut penelitian yang dilakukan Pan dkk (1997) tentang Effects of diet and exercise in preventing NIDDM in people with impaired glucose tolerance: The da qing IGT and diabetes study didapatkan hasil kombinasi diet dan latihan jasmani secara efektif menurunkan secara progresif kadar glukosa darah (American Diabetes Association, 2009). Boule dkk (2003) dalam penelitiannya yang berjudul Effects of exercise on glycemic control and body mass in type 2 diabetes mellitus: A meta-analysis of controlled clinical trialse menunjukkan hasil program latihan terstruktur secara statistik dan klinik memberikan pengaruh manfaat yang signifikan terhadap kontrol glukosa dan pengaruh ini tidak begitu signifikan terhadap penurunan berat badan

Salah satu dari latihan jasmani adalah senam kaki. Senam kaki dapat meningkatkan aliran darah dan memperlancar sirkulasi darah, hal ini membuat lebih banyak jala-jala kapiler terbuka sehingga lebih banyak reseptor 
insulin yang tersedia dan aktif (Soegondo, 2009). Kondisi ini akan mempermudah saraf menerima nutrisi dan oksigen yang mana dapat meningkatkan fungsi saraf (Guyton \& Hall, 2007). Senam kaki adalah kegiatan atau latihan yang dilakukan oleh pasien diabetes melitus untuk mencegah terjadinya luka dan membantu melancarkan peredaran darah bagian kaki. Senam kaki ini bertujuan untuk memperbaiki sirkulasi darah sehingga nutrisi ke jaringan lebih lancar, memperkuat otot-otot kecil, otot betis, dan otot paha, serta mengatasi keterbatasan gerak sendi yang sering dialami oleh pasien Diabetes Melitus (Wibisono, 2009).

Penelitian yang dilakukan oleh Patricia et al. pada tahun 2012 tentang The effect of exercise on neuropathic symptoms, nerve function, and cutaneous innervation in people with diabetic peripheral neuropathy. Hasil dari 17 sampel yang mengikuti senam aerobic mengalami penurunan dalam tingkat nyeri, gejala neuropati dan peningkatan serabut saraf intraepidermal bercabang dari biopsi kulit proksimal.

Senam kaki ini sangat dianjurkan untuk pasien diabetes yang mengalami gangguan sirkulasi darah dan neuropathy di kaki, tetapi disesuaikan dengan kondisi dan kemampuan tubuh pasien. Gerakan dalam senam kaki diabetes seperti yang disampaikan dalam 3rd National Diabetes Educators Training Camp tahun 2005 dapat membantu memperbaiki sirkulasi darah di kaki. Mengurangi keluhan dari neuropathy sensorik seperti: rasa pegal, kesemutan, gringgingen di kaki. Manfaat dari senam kaki diabetes yang lain adalah dapat memperkuat otot-otot kecil, mencegah terjadinya kelainan bentuk kaki, meningkatkan kekuatan otot betis dan paha (gastroenemius, hamstring, quadriceps), dan mengatasi keterbatasan gerak sendi, latihan seperti senam kaki diabetes dapat membuat otot- otot di bagian yang bergerak berkontraksi (Soegondo, 2009). Senam kaki diabetes ini dapat diberikan kepada seluruh pasien diabetes melitus dengan tipe 1 maupun 2. Namun sebaiknya diberikan sejak pasien didiagnosa menderita diabetes melitus sebagai tindakan pencegahan dini.

Hasil penelitian yang dilakukan oleh Alfiyah dan Virgianti (2010), tentang pengaruh senam kaki terhadap peningkatan sirkulasi darah kaki pada pasien diabetes mellitus di puskesmas Mantup Kecamatan Mantup Kabupaten Lamongan. Hasil penelitiannya menunjukkan sebelum diberi perlakuan senam kaki pada pasien Diabetes Melitus nilai ABPI yaitu lebih dari sebagian besar mengalami penyakit arteri ringan yaitu 18 orang $(60 \%)$ dan nadi yaitu lebih dari sebagian besar mengalami bradikhardi yaitu 16 orang $(53,3 \%)$ dan setelah diberikan perlakuan senam kaki mengalami peningkatan yaitu untuk nilai ABPI sebagian besar mengalami sirkulasi darah normal 15 orang $(50 \%)$ dan nadi lebih dari sebagian besar mengalami nadi normal sebanyak 19 orang $(63,3 \%)$.

Menurut Ocbrivianita Mulyaningtyas Utomo dkk (2012), dalam penelitian pengaruh senam terhadap kadar gula darah pasien diabetes di RS.Panti Wilasa Dr.Cipto Semarang, hasilnya dari sampel yang berjumlah 42 orang terdapat perbedaan kadar gula darah sewaktu sebelum dan sesudah intervensi. Penurunan rata-rata gula darah pada kelompok terpapar 2,3 kali lebih besar daripada kelompok tidak terpapar $(31,5 \mathrm{mg} / \mathrm{dl}$ berbanding 13,5 mg/dl). Tujuan dari penelitian ini untuk mengetahui pengaruh senam kaki terhadap kadar gula darah pasien diabetes mellitus di RSUD Kabupaten Serang

\section{BAHAN DAN METODE}

Penelitian ini merupakan jenis penelitian kuantitatif dengan desain penelitian yaitu quasi eksperimental one group pretest-posttest. pada penelitian ini menggunakan metode pengambilan sampel aksidental atau convenience sampling dengan kriteria inklusi. Penelitian ini dilakukan di RSU Serang, yaitu peserta senam diabetes (Persadia Cabang Serang). Penelitian ini dilakukan pada minggu ke-4 
bulan September 2014, pelaksanaan intervensi dilakukan selama 1 minggu.

Alat pengumpul data yang digunakan meliputi orang yang melatih, orang yang mengobservasi dan alat yang digunakan. Orang yang melatih senam kaki dilakukan oleh peneliti dan asisten peneliti yang telah mendapatkan pelatihan. Orang yang mengobservasi senam kaki adalah peneliti dan asisten peneliti yang telah diberikan apersepsi terhadap tool/instrument observasi senam kaki. Sedangkan macam alat yang digunakan adalah instrument untuk menilai senam kaki; dan alat yang digunakan untuk menilai kadar gula darah yaitu glukometer.

\section{HASIL DAN BAHASAN}

1. Hasil identifikasi gambaran karakteristik responden pada pasien pada pasien yang mengikuti senam diabetes mellitus di RSU Serang Tahun 2014.

Tabel 1

Distribusi frekuensi menurut usia, jenis kelamin, intensitas senam, dan konsumsi obat anti diabetes pada pasien yang mengikuti senam diabetes mellitus di RSU Serang Tahun 2014.

\begin{tabular}{|l|l|c|c|}
\hline Variabel & Karakteristik & $\mathrm{f}$ & $\%$ \\
\hline Usia & Muda & 8 & 36,4 \\
\hline & Tua & 14 & 63,6 \\
\hline Jenis Kelamin & Laki-laki & 10 & 45,5 \\
\hline & Perempuan & 12 & 54,5 \\
\hline Intensitas Senam & Teratur & 13 & 59,1 \\
\hline & Tidak Teratur & 9 & 40,9 \\
\hline Konsumsi OAD & Teratur & 13 & 59,1 \\
\hline & Tidak Teratur & 9 & 40,9 \\
\hline
\end{tabular}

2. Hasil penghitungan mean, SD dan nilai min - maks dari usia dan intensitas senam pada pasien diabetes mellitus di RSU Serang tahun 2014.

Tabel 2
Hasil penghitungan mean, SD, dan nilai min maks usia dan intensitas senam pada pasien yang mengikuti senam diabetes mellitus di RSU Serang Tahun 2014

\begin{tabular}{|c|c|c|c|}
\hline Variabel & Mean & SD & Min-Maks \\
\hline Usia & 44.86 & 8.962 & $32-62$ \\
\hline Intensitas Senam & 6.73 & 3.383 & $1-12$ \\
\hline
\end{tabular}

3. Kadar gula darah sebelum dan setelah mengikuti senam kaki yang diperoleh pada sesi 1, 2, dan 3 .

Tabel 3

Hasil penghitungan mean, SD, nilai min - maks kadar gula darah yang diperoleh pada sesi 1, 2, dan 3 sebelum dan setelah melakukan senam kaki pada pasien diabetes mellitus di RSU Serang Tahun 2014.

\begin{tabular}{|c|c|c|c|c|c|c|c|}
\hline Variabel & Sesi & Kelompok & $\mathrm{n}$ & Mean & SD & $\begin{array}{l}\text { Min- } \\
\text { maks }\end{array}$ & $95 \% \mathrm{CI}$ \\
\hline \multirow{6}{*}{$\begin{array}{l}\text { Kadar } \\
\text { gula } \\
\text { darah }\end{array}$} & \multirow[t]{2}{*}{1} & Sebelum & \multirow[t]{6}{*}{22} & 249.23 & 15.09 & $\begin{array}{l}221- \\
276\end{array}$ & $\begin{array}{l}242.5- \\
255.9\end{array}$ \\
\hline & & Setelah & & 237.27 & 14.50 & $\begin{array}{l}215- \\
276\end{array}$ & $\begin{array}{l}230.84- \\
43.70\end{array}$ \\
\hline & \multirow[t]{2}{*}{2} & Sebelum & & 248 & 13.66 & $\begin{array}{l}223- \\
273\end{array}$ & $\begin{array}{l}241.94- \\
254.06\end{array}$ \\
\hline & & Setelah & & 240 & 12.68 & $\begin{array}{l}220- \\
266\end{array}$ & $\begin{array}{l}234.38- \\
245.62\end{array}$ \\
\hline & \multirow[t]{2}{*}{3} & Sebelum & & 245.55 & 12.44 & \begin{tabular}{|l|}
$217-$ \\
267 \\
\end{tabular} & $\begin{array}{l}240.03- \\
251.06 \\
\end{array}$ \\
\hline & & Setelah & & 239.64 & 12.96 & $\begin{array}{l}217- \\
267\end{array}$ & $\begin{array}{l}233.89- \\
245.38\end{array}$ \\
\hline
\end{tabular}

Dari hasil penelitian dari 22 responden, 14 responden dari kelompok usia diatas 40 . Hal ini sesuai dengan Black dan Hawks (2005), DM tipe 2 merupakan tipe dari penyakit DM yang tidak bergantung insulin, penyakit ini sering terdiagnosa pada orang dewasa berumur lebih dari 40 tahun. Hasil penelitian ini menemukan bahwa kelompok yang banyak terdiagnosis diabetes adalah perempuan, dengan jumlah responden 12 orang $(54.5 \%)$. Menurut Taylor, hal ini disebabkan oleh penurunan kadar hormon estrogen akibat monopause. Estrogen pada dasarnya berfungsi untuk menjaga keseimbangan kadar gula darah dan meningkatkan penyimpanan lemak, serta progesteron yang berfungsi untuk 
menormalkan kadar gula darah dan membantu menggunakan lemak sebagai energi (Taylor, 2008). Hormon estrogen dan progesteron mempengaruhi sel-sel merespon insulin. Setelah menopause, perubahan kadar hormon akan memicu fluktuasi kadar glukosa darah, hal ini yang menyebabkan kejadian DM lebih tinggi pada wanita dibanding pria (Mayoclinic, 2010).

Menurut penelitian Brama (2012) latihan jasmani dapat memperbaiki sensitivitas insulin. Prinsip latihan harus memenuhi beberapa hal; jumlah olahraga perminggu dilakukan secara teratur 3-5 $\mathrm{x}$ permingggu, dengan intensitas ringan dan sedang, durasi 30-60 menit. Hal ini sesuai dengan hasil penelitian, bahwa responden yang teratur melaksanakan senam diabetes, memiliki nilai rata-rata kadar gula darah lebih kecil daripada responden yang tidak teratur melaksanakan senam diabetes.

Hasil penelitian yang didapat, untuk nilai rata-rata kadar gula pada responden yang teratur meminum obat anti diabetes jumlah dan presentasenya lebih tinggi daripada responden yang tidak teratur minum OAD, keteraturan minum obat diduga ada pengaruh terhadap penurunan kadar gula darah. Seperti halnya penelitian Wiwik Salistyaningsih (2011), bahwa Pasien DM tipe 2 di Puskesmas Umbulharjo II Yogyakarta ditinjau dari kadar glukosa darahnya, memiliki perbedaan yang bermakna antara pasien yang patuh dan tidak patuh dalam minum Obat Hipoglikemik Oral (OHO) dengan kadar glukosa darahnya

Berdasarkan hasil penelitian yang dilakukan, terdapat perbedaan selisih mean rata-rata kadar gula darah kaki sebelum dan setelah intervensi. Nilai rata-rata kadar gula darah setelah dilakukan senam kaki lebih rendah dari nilai kadar gula darah sebelum dilakukan senam kaki. Hal ini menggambarkan bahwa responden yang diberikan intervensi relatif memiliki nilai lebih rendah. Penurunan kadar gula ditunjukan oleh penelitian yang dilakukan oleh Pan, dkk (1997) tentang Effects of diet and exercise in preventing NIDDM in people with impaired glucose tolerance: The da qing IGT and diabetes study didapatkan hasil kombinasi diet dan latihan jasmani secara efektif menurunkan secara progresif kadar glukosa darah (American Diabetes Association, 2009). Begitu juga penelitian Tessierab, dkk (2000) menunjukkan hasil bahwa latihan fisik pada lansia memberikan pengaruh signifikan pada pengontrolan kadar gula darah selama uji toleransi glukosa oral. Boule dkk (2003) dalam penelitiannya yang berjudul Effects of exercise on glycemic control and body mass in type 2 diabetes mellitus: A metaanalysis of controlled clinical trialse menunjukkan hasil program latihan terstruktur secara statistik dan klinik memberikan pengaruh manfaat yang signifikan terhadap kontrol glukosa.

Menurut Ocbrivianita, dkk (2012), dalam penelitian pengaruh senam terhadap kadar gula darah penderita diabetes di RS.Panti Wilasa Dr.Cipto Semarang, hasilnya dari sampel yang berjumlah 42 orang terdapat perbedaan kadar gula darah sewaktu sebelum dan sesudah intervensi. Penurunan rata-rata gula darah pada kelompok terpapar 2,3 kali lebih besar daripada kelompok tidak terpapar $(31,5$ $\mathrm{mg} / \mathrm{dl}$ berbanding 13,5 mg/dl). Berdasarkan pada beberapa hasil penelitian di atas, menunjukan bahwa kadar gula darah pada orang yang mengalami diabetes melitus cenderung dapat dikontrol atau diturunkan dengan melakukan aktivitas. Aktivitas yang dilakukan harus dilakukan secara teratur, terukur dan dilakukan secara baik dan benar.

\section{KESIMPULAN DAN SARAN}

Terdapat pengaruh senam kaki pada kadar gula darah dan perbedaan pengaruh usia terhadap perubahan rata-rata kadar gula darah antara sebelum dan setelah senam kaki. Untuk kelompok muda pengaruh senam kaki terbukti lebih efektif. Tidak ada pengaruh dari jenis kelamin terhadap senam kaki pada kadar gula darah. Terdapat perbedaan yang signifikan dari 
intensitas melakukan senam diabetes terhadap perubahan kadar gula darah. Mereka yang lebih lama melakukan senam diabetes mengalami penurunan kadar gula lebih tinggi setelah melakukan senam kaki. Terdapat perbedaan pengaruh yang signifikan dari konsumsi obat anti diabetes terhadap perubahan kadar gula. Mereka yang tidak teratur minum obat cenderung mengalami penurunan kadar gula darah lebih besar setelah melakukan senam kaki. Saran dalam penelitian ini bahwa senam kaki diabetes dapat dijadikan salah satu standar asuhan keperawatan yang dapat diaplikasikan dalam pelayanan keperawatan, baik di rumah sakit dan komunitas.

\section{DAFTAR PUSTAKA}

Alfiyah \& Virgianti. (2010). Pengaruh senam kaki terhadap peningkatan sirkulasi darah kaki pada pasien diabetes mellitus (DM) di puskesmas Mantup kecamatan Mantup Kabupaten Lamongan. STIKes Muhammadiyah Lamongan: Surya, Jurnal Media Komunikasi Ilmu Kesehatan.

Andrews, M. et al. (2005). Handbook of geriatric nursing care. Pennsylvania: Springhouse Corporation.

Arimuko. (2012). Melawan dan mencegah diabetes. Yogyakarta: Araska Printika.

Black \& Hawks. (2009). Medical Surgical nursing : management for positive outcome ( $8^{\text {th }}$ edition). St. Louis : Elsevier Saunders.

Boule, dkk. (2003). Effects of exercise on glycemic control and body mass in type 2 diabetes mellitus: A meta-analysis of controlled clinical trialse. Jurnal American Medical Association.

Bullock, J. (2001). Physiology (4th Edition).USA: Lippincott Williams and Wilkins.

Campbell N. A et al. (2005). Biologi Ed. 5 Jilid III. Jakarta: Erlangga.

Cochran, William G. (2005). Teknik Penarikan Sampel (ed. 3). Jakarta: UIPress
Dahlan, Muhamad Sopiyudin. (2012). Statistika untuk Kedokteran dan Kesehatan (Edisi 6): Deskriptif, Bivariat, dan Multivariat, Dilengkapi Aplikasi dengan Menggunakan SPSS. Jakarta: Salemba Medika.

Depkes. (2013). Laporan Hasil Riset Kesehatan Dasar Indonesia. Jakarta: Badan Litbangkes.

Faridah, Eva. (2012). Perbedaan Pengaruh Senam dan Fleksibilitas terhadap Penurunan Kadar Lemak dipinggang. GLADI JURNAL ILMU KEOLAHRAGAAN, Vol 6, No. 1.

Farizati, Karim. (2002). Panduan Kesehatan Olahraga Bagi Petugas Kesehatan. Depkes RI

Guyton \& Hall. (2007). Buku ajar Fisiologi Kedokteran edisi II, Jakarta: EGC

Ibrahim, Zaenal S. (2012). Pengaruh senam kaki terhadap peningkatan sirkulasi darah kaki pada pasien diabetes mellitus tipe 2 di RSUP Fatmawati Jakarta Tahun 2012. Universitas Pembangunan Nasional "VETERAN" Jakarta: Laporan hasil penelitian.

Indriani, Puji dkk. (2007). Pengaruh Latihan Fisik; Senam Aerobik Terhadap Penurunan Kadar Gula Darah Pada Penderita DM Tipe 2 Di Wilayah Puskesmas Bukateja Purbalingga. Media Ners, Volume I, No.2.

IDF. (2013). Diabetes Atlas edisi ke-6.

Joyce LeFever Kee. (2007). Pedoman Pemeriksaan Laboratorium dan Diagnostik. Jakarta: EGC.

Le Mone et all. (2011). Medical surgical nursing critical thinking in clien care, second edition. New York : Pearson Education, Inc.

Mangoenprasodjo, A. S. \& Hidayati, S. M. (2005). Terapi alternatif dan gaya hidup sehat. Yogyakarta: Pradipta Publishing.

M. Al-Musa, Hassan. (2013). Prevalence of diabetic foot and the associated risk factors at primary health care level in southwestern Saudi Arabia. Department of Family and Community 
Medicine, College of Medicine, King Khalid University, Abha, Saudi Arabia.

Notoadmodjo, Soekidjo. (2005). Metodologi Penelitian Kesehatan. Jakarta: PT. Rineka Cipta

Nursalam.(2008). Konsep dan Penerapan Metodologi Penelitian Ilmu Keperawatan : Pedoman Skripsi, Tesis, dan Instrumen Penelitian Keperawatan. Jakarta: Salemba Medika

Ocbrivianita, et al. (2012). Pengaruh senam terhadap kadar gula darah penderita diabetes. Universitas Negeri Semarang: Fakultas Ilmu Keolahragaan, Jurusan Ilmu Kesehatan Masyarakat.

Perkeni. (2011). Konsensus Pengelolaan Diabetes Melitus Tipe II di Indonesia. Jakarta: PB Perkeni.

Pratiknya, Ahmad Watik. (2007). Dasardasar Metodologi Penelitian Kedokteran dan Kesehatan. Jakarta: PT. Raja Grafindo Persada.

Prayitno, Ayu Prameswhari dkk. (2013). Efektifitas Senam Kaki Diabetes dengan Menggunakan Tempurung Kelapa Terhadap Kadar Glukosa Darah Pada Pasien DM Tipe 2. Program Studi Ilmu Keperawatan Universitas Riau

Priyanto, Sigit. (2012). Pengaruh senam kaki terhadap sensitivitas kaki dan gula darah pada agregat lansia diabetes mellitus di Magelang. Jakarta: Program Studi Magister Ilmu Keperawatan FIK-UI.

Probosuseno. (2007). Mengatasi Isolation pada Lanjut Usia. http//www.medicalzone.org.

Riyadi. (2004). Tingkat pengetahuan dengan deteksi diabetes melitus.

http://digilib.unimus.ac.id/download.php?i $\mathrm{d}=4685$.

Rohani. (2013). Pengaruh kombinasi senam diabetes mellitus dan senam kaki diabetik terhadap penurunan kadar gula darah pasien diabetes mellitus tipe 2 anggota persadia $R S$
Husada. Program Studi Magister Ilmu Keperawatan UMJ.

S, Sumosardjuno. (1986). Manfaat dan

Macam Olahraga bagi Penderita

Diabetes Melitus. Bandung.

Sacher \& Richard. (2004). Tinjauan Klinis Hasil Pemeriksaan Laboratorium. Jakarta: EGC.

Sastroasmoro, S. (2010). Pemilihan Subyek Penelitian. Dalam: Sastroasmoro, S., 2010. Dasar-dasar Metodologi Penelitian Klinis Ed.3 Cet.2 . Jakarta: Sagung Seto

Sefty Maidina, Tria. et al. (2012). Hubungan kadar HbAlC dengan kejadian kaki diabetic pada pasien diabetes melitus di RSUD Ulin Banjarmasin. Universitas Lambung Mangkurat Banjarmasin: Fakultas Kedokteran.

Sherwood L. 2006. Textbook of human physiology edisi 2. Jakarta: EGC.

Sihombing, D. (2012). Gambaran perawatan kaki dan sensasi sensorik kaki pada pasien diabetes mellitus tipe 2 di poliklinik DM RSUD. http://journals.unpad.ac.id/ejournal/art icle/view/677.

Smeltzer, S.C \& Bare, B.G. (2008). Brunner \& Suddart: Textbook of medical surgical nursing. Philadelphia: Lippincott.

Sugiyono. (2012). Statistik Untuk Penelitian. Bandung : Alfabet

Salistyaningsih, Wiwik dkk. (2011). Hubungan Tingkat Kepatuhan Minum Obat Hipoglikemik Oral dengan Kadar Glukosa Darah pada Pasien Diabetes Melitus Tipe 2. Program Studi Kesehatan Masyarakat Universitas Respati Yogyakarta: Berita Kedokteran Masyarakat, Vol. 27, No. 4.

Soegondo S. 2009. Penatalaksanaan diabetes melitus terpadu. Jakarta: FKUI.

Tandra, Hans. (2007). Segala sesuatu yang harus anda ketahui tentang DIABETES, Jakarta: PT Gramedia Pustaka Utama 
Tortora GJ, Derrickson B. (2011). Principles of anatomy and physiology 13th ed. John Wiley and Sons (Asia) Pte Ltd. Singapore.

Word Health Organization. (2000). Pencegahan Diabetes Mellitus. Jakarta: Hipokrates.

WHO. (2013). Global status report on noncommunicable diseases (NCDs).

Waspadji S. (2005). Diabetes Mellitus :

Mekanisme dasar dan pengelolaannya yang rasional. Dalam Soegondo S dkk (eds), Penatalaksanaan Diabetes Melitus Terpadu. Jakarta: FKUI.

Wibisono. (2009). Senam Khusus Untuk Penderita Diabetes.
Yunir \& Soebardi. (2009). Terapi non farmakologis pada diabetes mellitus. Dalam Sudoyo AW, dkk (eds), Buku ajar ilmu penyakit dalam jilid III, edisi IV. Jakarta: Pusat Penerbitan Departemen Ilmu Penyakit Dalam FKUI.

Zaenurokhim, K. Anwar dkk. (2012). Pengaruh Senam Kaki Terhadap Perubahan Tekanan Darah Pada Klien DM Tipe 2 Di Wilayah Puskesmas Kedungwuni 2 kabupaten Pekalongan Tahun 2012. STIKES Muhammadiyah Pekajangan

http://senamkaki.com. 